\title{
1. The essence and basic methods of the pure theory
}

\subsection{THE MEANING OF PURITY}

Hans Kelsen's pure theory of law fascinates as many observers as it alienates. There certainly is a tendency to regard Kelsen's theory as too structured, categorical, formalistic and unsuitable to the empiricism and alleged dislike for the abstract principle in common law jurisdictions. But English law is still a system consisting of rules prescribed by constitutionally established authorities, and it has to operate as a single coherent whole for its viability and legitimacy to be preserved, and for it to avoid dissolving into, or being seen as, a set of arbitrary prescriptions and procedures whose legitimacy could, at times, be questioned.

This analysis requires the exposition of basic categories of pure theory as one of the most complex theories of the law, clarifying their essence, before the relevant matters arising in English law can be examined through the prism of this theory.

The purity of legal method is meant as no more and no less than a consistent presentation of positivism, using only and exclusively the positivist legal method to explain the validity and content of legal norms, and distinguish these norms from social, political and ethical considerations that may historically or sociologically account for the creation of those legal norms.

The basic task of the pure theory distinguishes this theory from all other legal theories. The pure theory 'seeks to discover the nature of law itself, to determine its structure and its typical forms, independent of the changing content which it exhibits at different times and among different peoples'. ${ }^{1}$ Thus the "pure theory of law ... is a science, and not meta-physics. This science seeks the real and possible law, not the just, and in this sense it is radically realistic and empirical. It declines to justify or condemn. ${ }^{2}$ The cognition and understanding of legal systems, not their assessment or critique, nor their

1 H Kelsen, The Pure Theory of Law and Analytical Jurisprudence, 55 Harvard Law Review (1941), 44 ('HLR').

2 HLR, 49. 
defence or approval, or any attack against them and their disapproval. The pure theory is neither apologetic nor critical with regard to any legal system whatsoever.

Kelsen's own statement illustrates the extent of the contrast as part of the statement of the pure theory's mission: 'Only norms, provisions as to how individuals should behave, are objects of jurisprudence, never the actual behavior of individuals.' Furthermore, 'the propositions of jurisprudence are not themselves norms. They establish neither duties nor rights. Norms by which individuals are obligated and empowered issue only from the law-creating authority ... It is of the greatest importance clearly to distinguish between legal norms which comprise the object of jurisprudence and the statements of jurisprudence describing that object.' ${ }^{3}$

Recognising jurisprudence as a source of law is compatible with the natural law approach, but not with the legal positivism. 'The ought-statements in which the theorist of law represents the norms have merely a descriptive import; they, as it were, descriptively reproduce the "ought" of the norms'. ${ }^{4}$ It is, therefore, highly important to distinguish between legal norms which are the product of the law-creating process and object of jurisprudence, and the statements of jurisprudence. Kelsen refers to the view of Joseph Bingham that:

If we are to view the law as a field of study analogous to that of any science, we must look at it from the position of the law teacher, the law student, the legal investigator, or the lawyer who is engaged in searching the authorities to determine "what the law is'. These men are not directly acting as part of the machinery of government. Their study is not part of the external phenomena which compose the field of law. They are studying that field from without and therefore from the position which will give a wholly objective and the least confusing view. ${ }^{5}$

\subsection{METHODOLOGY AND THE ESSENCE OF LEGAL KNOWLEDGE}

Kelsen explains that 'there is no essential difference between analytical jurisprudence and the pure theory of law. While they differ, they do so because the pure theory of law tries to carry the method of analytical jurisprudence more consistently than Austin and his followers. ${ }^{6}$ The pure theory aims to be the most comprehensive guide to understanding the positive law. Thus it aims not at being a new theory, but merely at the progression of positivist reasoning right down the line.

HLR, 50-1; H Kelsen, General Theory of the Law and State (1940) ('GT'), 163.

$G T, 163$.

J Bingham, What is the Law? 11 Michigan LR (1912), 10.

GT, XV; HLR, 54. 
The purity of the legal method means no more, and no less, than that the legal theory answers all questions solely through the use of the positivist method. It addresses the positive law as a whole, from the point where the authority producing law is established to the point where the law is ultimately enforced or applied with regard to the conduct of individuals. The purity of the legal method does not mean having an adverse view on non-legal considerations or pronouncing them irrelevant. They are just separate from legal considerations that form the object of the pure theory. Kelsen explains that 'every assertion advanced by a science of law must be based on a positive legal order or on a comparison of the contents of several legal orders'. Purity of legal method is secured through separation of positive law analysis from legal sociology and philosophy of justice. ${ }^{7}$ Pure theory was the methodische Selbstbesinnung of legal science, meant to be an independent discipline rather than part of sociology, and the foundation of legal science as science. ${ }^{8}$ This priority was meant to avoid placing the legal theory at the service of any political or economic agenda. ${ }^{9}$ The anti-ideological character of pure theory turns it into a true science of law. ${ }^{10}$

Kelsen's drive to separate the legal method from that of sociology, ethics or other disciplines has set his theory against both of the jurisprudential tradition established across the continental-common law divide, against the background of which he was developing his own theory, and of the multiple theoretical approaches developed subsequently. Much as the inclination to study not the law as such but the law in connection with some extra elements is represented in several modern theoretical approaches, it has been characteristic of legal science since the nineteenth century at the latest.

To illustrate, Rudolf von Ihering has claimed that legal science 'has the purposive as its object', 'experience having reference to the assured attainment of certain human purposes'. ${ }^{11}$ Roscoe Pound was emphasising that ' $[t]$ he futility of a self-sufficing, self-centered science of law has become apparent to jurists'. Pound, however, admitted that a proper study of social interests, of subserving them and of the actual social effects of legal institutions and legal doctrines cannot be performed by courts, law-teachers or law-writers, 'except within narrow limits'. ${ }^{12}$ In other words, the limits on the reach of legal methodology

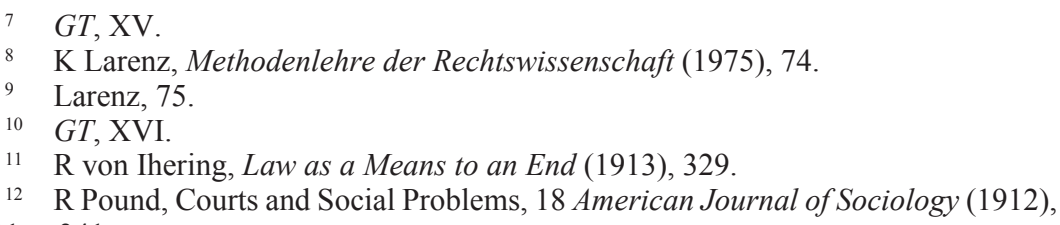


are by and large obvious to those finding themselves at various ends of the doctrinal spectrum.

The purity of the law and legal method runs into the broader inter-disciplinary and social implications of legal systems that no doubt generate the discussion of the range of values on which various parts of the society hold different views. One commentator suggests that:

So long as logical consistency is one of the aims of legal science some logical model justifying non-contradiction and subsumption is an essential part of legal theory. Kelsen's model, it is submitted, is the best which theory has so far achieved. However, there are other aims which legal scientists commonly set themselves, such as the historical and sociological explanation of the origin and application of rules of law, the moral or political justification or criticism of such rules, and policy-oriented suggestions for the interpretation of such rules in doubtful cases and for the enactment or repeal of such rules. Kelsen's theory, by insisting on 'pure' cognition - that is, the logically consistent arrangement of legal source materials without reference to history, purpose or policy - as the hallmark of legal science, impliedly downgrades these other aims. ${ }^{13}$

Kelsen does not downgrade the relevance of non-legal considerations, but merely delimits the scope of his own theory. A preference for doing one thing at a time is not the same as insisting that other things ought not to be done.

Another commentator has suggested that, 'if we were to construe Kelsen's theory of law and the state as a neutral, unqualifiedly agnostic theory ... this would mean that as a matter of principle we have deprived ourselves of a full understanding of that theory, deliberately choosing not to take into account its complex and multiform ideal valence'. ${ }^{14}$ Furthermore, '[t]he pure theory of law is a relativistic theory, to be sure, but it does not resolve itself into an absolute scepsis. Kelsen's relativism is itself relative, in that it presupposes an all-embracing value, that of tolerance. ${ }^{15}$

Kelsen's own take is that what he does not want to presume is that the essence of the law, to be cognised scientifically, depends on or is nourished by some extra-legal factors. The pure theory does not require one to believe that God does not exist or to be uncertain about his existence, nor to hold that socio-political or ethical forces play no role in the development of the law. The pure theory merely emphasises that the law is a system of its own, being a creature of human societies and, to operate properly, a legal system must be

13 JW Harris, When and How Does the Grundnorm Change? 29 CLJ (1971), 112.

14 A Carrino, Logistic Normativism: The Wiener Rechtstheoretische Schule, in E Pattaro and C Roversi (eds), Legal Philosophy in the Twentieth Century: The Civil Law World (2016), 75.

15 Carrino, 75. 
able to give to its prescriptions such meaning as are determined by that legal system itself.

It may be discussed whether or how being a vegetarian impacts the biological development of a human body or more broadly is conducive to the environment, or is required on ethical grounds; whether a mechanical engine is workable and feasible or whether its operation is financially onerous or environmentally harmful. Those broader considerations attending every single such matter notwithstanding, no rational man would deny that biological organisms or mechanical engines can and should be studied by reference to their own inherent elements and characteristics, within the methodological framework of the relevant disciplines, if only because only after the analysis through that 'narrower' specialised methodological framework would it be possible to identify the broader impact of the relevant phenomena. Thus, no one criticises physics, mechanics or biology because they are 'agnostic' to ethics, and there is no reason why the law should not be treated in the same way.

Similarly, there can be no single theory explaining all aspects of social life (which is why we have a number of social sciences), but there can be a theory explaining all aspects of one particular area of social life, in this case legal systems. The pure theory singles out its own object, pursues it with analytical rigour and precision; and leaves other aspects to other theories to handle.

Kelsen explains that jurisprudence creates legal concepts, while a legal order creates legal norms on the basis of which legal science creates legal concepts. Legal science does not create rules the way geometry shapes objects and bodies. ${ }^{16}$ It addresses the legal regulation of objects that already exist and represent the natural or social reality.

In this respect, Kelsen has contrasted his methodology to that of the organic theory of the law and State. An overall characteristic of the organic theory is that it does not strictly delineate the boundaries between legal observation and sociological observation, and recognises no firm boundary between the law and sociology. It is based on the monist perception that views social and legal phenomena as part of the single category, which is opposed by the dualist world view which enables the development of juridical theory of State and law. ${ }^{17}$

The essence of the monist approach in this area is the insistence that everything must be seen as having the socio-organic nature, and that nothing different from that could possibly exist. This way the legal theory in effect ends up importing the methodology of other social sciences at the risk or at the

16 H Kelsen, Hauptprobleme der Staatsrechtslehre Entwickelt aus der Lehre vom Rechtssatze (1923) ('Hauptprobleme'), 94.

17 Hauptprobleme, 177. 
cost of compromising or even displacing the integrity of the legal methodology it is supposed to be using. Thus the pure theory insists upon the limitation of the task of legal science, its concentration on the substance and content of actual law enacted by constitutionally empowered authorities, which gives the separate content and distinct methodological edge to legal science.

The pure theory makes legal norms (rules) the chief object of its scientific cognition. Legal norms are not the only kind of norms and the law is not the only system of norms. However, the law differs from other normative systems in that it can be ascertained by reliance on the evidence that is external to the mind and consciousness of the one who tries to take cognition of it. Such external evidence relates to the authority that lays down laws binding on individuals and other entities regardless of the latter's will. On the same conditions, such laws are positive laws that can be enforced by the same system which lays it down.

Obviously, the law is not the only normative system that constrains people in their actions, and in all societies people do feel constrained by moral and ethical imperatives in their mutual relations. Similar to law, other normative systems, even ethical and moral norms generally accepted in a particular society come in conflict with interests and aspirations of individuals; a particular individual might see a moral and ethical norm just as intrusive to its freedom or interests and just as discomforting as some individuals would see the rules of positive law. However, the law differs from other normative systems by impacting individual freedom through the operation of a system external to those individuals' wishes, desires, feelings and motivations. The legitimacy of the system, regulation, and enforcement all are external to the individual's existence and preferences. The pure theory examines this process of external impact from start to finish.

The principal feature of the law is its regulatory function and normativity; before the law is a coercive system, it is a system of norms that regulate human behaviour, i.e. prescribe the conduct required from the norm's addressee, and thus provide for the criteria that distinguish lawful from unlawful activities. Asking what exactly is binding and enforceable through coercion is analytically anterior to speaking about that coercion and enforcement. Law's impact on the individual freedom, and thus on real life, begins with its regulatory function.

The connection between the authority behind legal norms conferring binding force to them, the content of those norms, and the entitlement of the system to enforce those norms exposes the principal connection between the nature of positive law and the fact that individuals are free and autonomous units unless constrained in their conduct and freedom by rules of that positive law.

As suggested, "Authority" is a specific justification for accepting a prescription precisely when the prescription does not follow with inferential clarity 
from other prescriptions we already accept ... inference is not required for authority. ${ }^{18}$ In other words, positive legal norms have the binding force, which does not depend on any further or alternative justification or rationalisation. The content of legal norms cannot be identified through judgement, deduction or appreciation. Instead, it has to be identified from the will of the constitutionally empowered law-making authority.

Owing to the impact positive law has on individual freedom, it is qualitatively distinct from other normative systems, and it should be studied on its own merit and separately from those other systems as well. This is what pure theory does.

\subsection{BASIC CONCEPTS AND THEIR FORMATION}

Every theory has to provide its own thinking categories to further develop its analysis. The pure theory's outlook has been impacted upon by Kelsen's neo-Kantian orientation that emphasises the relevance of concepts in enabling the study of evidence by organising empirical evidence meaningfully. ${ }^{19}$ As a starting point, one wonders whether there is any inherent contradiction between conceptualism and empiricism, whether experience can be meaningfully studied without in the first place identifying its meaning, scope and relevance. In addition, the extent to which empiricism can be prioritised can depend on the aims of a particular theory. Legal sociology will focus on predicting legal outcomes. By widening or narrowing down the range of the data and experience to be studied and treated as relevant, each theory may arrive at conclusions that are not cognisable under, or directly contradict the findings of, any other theory.

Like many other theories, the pure theory proposes its own basic concepts that enable it to follow through the scientific take on law through elaboration of concepts. This process of the elaboration upon concepts is meant to secure the pure theory's analytical economy. Most importantly, therefore, the relevance of concepts for the pure theory is rather minimalistic, focused on common denominators of all legal systems. The pure theory's concepts are so framed as to allow capturing the identification of features of any particular legal system developed pursuant to the experiences of that legal system.

The mutual coherence of legal concepts is not just a theoretical whim; legal theory addresses the legal order that, just like any other mechanism or machinery, operates as a system of mutually supportive and reinforcing elements.

\footnotetext{
18 JW Harris, Kelsen's Concept of Authority, 36 CLJ (1977), 353 at 358.

19 Cf. R Cotterrell, The Politics of Jurisprudence - A Critical Introduction to Legal Philosophy (1989), 107.
} 
A coherent or plausible legal theory has to adopt the same attitude towards coherency. Then, the level of theorisation adopted, high or low, is meant to capture the basic elements of legal systems as they actually operate, not just as they are perceived by theoretical or ideologically minded observers.

Kelsen explains that any concept consists of its features or elements that are so essential to it that without them that concept would lose its essence. ${ }^{20}$ Only such features or elements count in which the legal method is distinctly interested, as opposed to categories of ordinary perception that may arise with regard to the operation of any legal system.

As we shall see throughout this study, nothing that could be analytically avoided or evaded is presupposed by the pure theory; concepts are needed to explain what actually happens within the legal system. Then, the reduction of those concepts to ideas and elements that could be derived from simple modes of human thinking (Denkmodus) not only secures the pure theory's analytical economy but also provides these concepts with analytical transparency and makes them incontestable.

As the law is the sole object of cognition of the positivist legal science, the meaning of concepts it uses should be independent from anything that the system of law does not incorporate in itself. Accordingly, if somewhat critically, it has been noted that with the pure theory, " $[\mathrm{t}]$ he state is in the first place desubstantivized, "formalized," and resolved into the pure relations of the legal norm, and justice is reduced to the positive law'. ${ }^{21}$

Other concepts that also appear as categories of ordinary perception are also defined by the pure theory in the manner that appears suitable for the positivist legal methodology. To illustrate, duty is defined as one prescribed by constitutionally empowered authorities, as distinguished from duty perceived as value in the philosophical tradition (such as with Kant). ${ }^{22}$

A further implication of using this methodology is that concepts are presented as complexes of legal norms, not ones invented by the pure theory but as ones created by the legal system.

\subsection{IS AND OUGHT}

There are two principal elements with which the pure theory operates: Is (Sein), which relates to actual facts on the ground, the actual state of affairs; and Ought (Sollen), which is about facts and outcomes as the law requires them

Hauptprobleme, 577.

Carrino, 79.

22 For overview see Larenz, 82-3. 
to be. ${ }^{23}$ Kelsen further explains that the essence of Sollen is premised on the distinction between laws of nature, dealing with what will inevitably happen, and juridical laws that stipulate what ought to happen. ${ }^{24}$ It is the latter to which Sollen relates, whereby its embodiment of the elements of will, command and prescription is exposed.

The element of Sollen is a key implication of law's normativity, set of normative prescriptions or requirements, direction to someone, means of ruling and exercising authority. Thus Sollen emphasises the link between law and authority that creates it with a view to ruling and obtaining obedience and, finally, authorising coercion should the rule in question not be complied with. Goodhart engages the use of terms such as command and obligation, and considers that obligation is preferable to command and proposes to 'define law as any rule of human conduct which is recognised as being obligatory', which is antithesis to voluntary. ${ }^{25}$ But these fine terminological distinctions are beside the point, because anything that is obligatory derives from the authority of someone entitled to command it.

By singling out Sein and Sollen as chief elements with which the pure theory is operating, Kelsen enhances the analytical economy of his theory, in the sense that legal theory is seen as dealing with the relationship between fact and law. Positive law regulates and applies to facts, which is the whole essence of the legal process, to the exclusion of the range of extra-legal values or interests. Validity and legal force of a legal prescription is not identical with its actual application or enforcement

Sein and Sollen are basic categories of thinking (Denkmodus). They are too basic and obvious to need any further explanation. They are immediately present in the human consciousness. ${ }^{26}$ At the same time they are substantially different from each other, and coincidence between them in real life cannot be assumed across the board.

These basic categories, deeply rooted in human consciousness, help explain the relationship between regulatory and enforcement functions of a positive legal order and the actual state of affairs on the ground, including the conduct and wishes of individuals who are the addressees of such legal regulation and enforcement.

\footnotetext{
23 It must be emphasised here that the meaning of these terms has been misrepresented in some pieces of analysis of Kelsen's theory. See, e.g., H Lauterpacht, Kelsen's Pure Science of Law, Modern Theories of Law (1933), 107, describing Sollen as 'category of essence', as opposed to Sein which is a 'category of existence'. W Friedmann, Legal Theory (5th edn, 1964), 284, describes Lauterpacht as a follower of Kelsen.

${ }_{24}$ Hauptprobleme, $3 \mathrm{ff}$.

25 A Goodhart, English Law and the Moral Law (Hamlyn Lectures 1953), 19.

26 H Kelsen, Reine Rechtslehre (1934) ('RR'), 5.
} 
Legal norms belong to the realm of Sollen. Sollen is a broad category that encompasses anything that ought to be, including the elements of permission, entitlement or obligation. ${ }^{27}$ Hart correctly emphasises that " "Ought" in Kelsen's usage is a kind of deontic variable ranging over what he terms prescriptions (or commands), permissions and authorizations. ${ }^{28}$ If someone is legally permitted or entitled to do something, then they ought to be able to do it within the range of that permission or entitlement. In other words, Sollen is about something that ought to be, not just about things that someone ought to do.

Law and contract are binding because the legal system requires they ought to be complied with and that the agency or entity which produces them has the authority to produce binding rules and prescriptions. The adoption of a legislative act or conclusion of a contract are facts, and the law links to them certain consequences that follow not from those discrete facts themselves, but from the relevance the legal system attaches to them. Law-creating fact is itself an Is but it produces an Ought, which process is accounted for by another norm, created through a different, preceding, law-creating fact which has produced another Ought to the effect that rules produced according to a certain procedure are binding.

A provision in a statute that theft is punishable by so and so many years of imprisonment is not a statement of actual event; it is instead a command, a prescription as to what ought to be done in the case of theft. The fact that parliament has adopted the 1968 Theft Act amounts to an Is. The will that it expressed through its provisions produces a series of Ought. The proposition under the 1968 Theft Act that '[a] person is guilty of theft if he dishonestly appropriates property belonging to another with the intention of permanently depriving the other of it' (section 1(1) of the Act) is liable to imprisonment for up to seven years means that any person who carries out such conduct ought to be brought before justice and the court ought to sentence them accordingly; not that they are always in fact apprehended or so sentenced.

\subsection{LAW AND OTHER NORMATIVE SYSTEMS}

Legal norms are similar to ethical, moral or religious norms in the sense that they all stipulate an Ought ${ }^{29}$ in the sense that they all stipulate what is right or wrong, what is required or prohibited..$^{30}$ Moral norms are prescriptive, independent for validity from the disposition, will or action of individuals, yet

\footnotetext{
$27 \quad R R, 4-5$.

28 HLA Hart, Kelsen's Doctrine of the Unity of Law, in Hart, Essays in Jurisprudence and Philosophy (1984), 328.

29 Hauptprobleme, 70.

30 Larenz, 81.
} 
moral norms have emerged through society practising them, and cannot exist unless they are widely followed by the conduct of individuals and manifest that they are generally accepted in a society.

However, a legal Ought is different from other prescriptions in the following ways: it is a product of the will of a person or organ; its validity turns on its correspondence with the procedures and authorities operating under the basic norm of the legal system; and it entitles (though not necessarily obliges) another person or organ to undertake sanction or coercion with a view to enforcing that legal Ought. The coercion element is not only defined as a necessary implication of legal norms being binding norms, but also, and in order for a particular use of coercion to be described as an element of legal order, it presupposes some antecedent determination of the conduct required, of the right and wrong proclaimed by the organ constitutionally so empowered, as a precondition for coercion to be applied. ${ }^{31}$

\subsection{BINDING FORCE AND APPLICATION OF LEGAL NORMS}

With legal norms, not being followed does not have the same significance as it has with moral norms. A legal norm lives a life other than one related to it being followed. Application of legal norms takes place in cases when they are not followed or observed. ${ }^{32}$ Kelsen explains that 'a single legal norm may be valid but not efficacious in a concrete instance, because as a matter of fact, it was not obeyed or applied although it ought to have been'. An 'Ought' expresses the idea of validity of norm. ${ }^{33}$ Hart has also expressed the similar position about the relationship between validity and efficacy of legal rules that replicates Kelsen's. ${ }^{34}$

A legal norm's validity does not depend on how often it is applied in practice, but on the voluntary law-creating act. Development of the law and authority of law are two different things, in their turn leading to the distinction between the historical study of the law and its dogmatic observation. ${ }^{35}$

If the legal essence of a legal norm includes its observance or application, thus if Sein and Sollen are mutually interdependent or identical, that defeats

31 See further Ch. 6 on the rule of law.

Hauptprobleme, 49.

HLR, 51.

34 "If by "efficacy" is meant that the fact that a rule of law which requires certain behaviour is obeyed more often than not, it is plain that there is no necessary connection between the validity of any particular rule and its efficacy', HLA Hart, Concept of Law (1961), 103 (emphasis original).

35 Hauptprobleme, 38-9. 
the whole arrangement of legal order, ${ }^{36}$ because in such case the legal order would be unable to produce valid prescriptions and require obedience. Kelsen explains that legal norms are applied when they are not followed by their addressees. The effect (Wirkung) of the legal norm does not depend on the compliance with it. To the contrary, the rule begins operation when it gets violated by its addressee. ${ }^{37}$ The validity (Geltung) and effect (Wirkung) of a legal norm is not the same as its actual application (Anwendung). ${ }^{38}$ The separateness between these concepts is inevitable if the discrete meaning is to be attached to the authority that enacts the norm and to public interest that leads the authority to enact them.

A legal norm is not a cause of human conduct subsumable within the norm's scope, but provides merely a measure of judgement (Beurteilungsmaßstab) with regard to the fact that already has occurred, to ascertain whether it is a fact whose occurrence the norm has required or mandated. ${ }^{39}$ Acts contrary to law (Unrecht) are not exceptions to a legal norm, but they could be endowed with normativity only through a rule substantially different from one that makes it unlawful. ${ }^{40}$ Factual deprivation of the norm's legal force (faktisches Ausserkraftsetzen) or destruction of a norm through factual conduct is unimaginable. ${ }^{41}$ Thus, a rule declaring $\mathrm{X}$ as unlawful does not admit any exceptions, any and every $\mathrm{X}$ is therefore unlawful. The validity and scope of a legal norm does not turn on the compliance with it, nor on its enforcement by public authorities. As the UK Supreme Court specified in $R v G u l$ with regard to the exercise of prosecutorial discretion:

Where the consent of the DPP or the Attorney General is required, their respective responsibilities are exercised for the unexceptionable purpose of ensuring that a prosecution should not be instigated nor proceed if this would not be in the public interest. However, the prosecutorial discretion was never intended, and as far as we can ascertain, it has never been suggested that it was ever intended, to assist in the interpretation of legislation which involves the creation of a criminal offence or offences. Either specific activities carried out with a particular intention or with a particular state of mind are criminal or they are not. ${ }^{42}$

\footnotetext{
Hauptprobleme, 50.

Hauptprobleme, 49-50.

Hauptprobleme, 15.

Hauptprobleme, 15.

Hauptprobleme, 55.

Hauptprobleme, 50-1.

$R v$ Gul [2013] UKSC 64, para. 35.
} 
The Supreme Court takes an even more robust stance in $G u l,{ }^{43}$ to the effect that:

The Crown's reliance on prosecutorial discretion is intrinsically unattractive, as it amounts to saying that the legislature, whose primary duty is to make the law, and to do so in public, has in effect delegated to an appointee of the executive, albeit a respected and independent lawyer, the decision whether an activity should be treated as criminal for the purposes of prosecution. Such a statutory device, unless deployed very rarely indeed and only when there is no alternative, risks undermining the rule of law. It involves Parliament abdicating a significant part of its legislative function to an unelected DPP, or to the Attorney General, who, though he is accountable to Parliament, does not make open, democratically accountable decisions in the same way as Parliament. Further, such a device leaves citizens unclear as to whether or not their actions or projected actions are liable to be treated by the prosecution authorities as effectively innocent or criminal - in this case seriously criminal.

If prosecutors do not prosecute an offence courts can do little; however, the negative approach to that matter is clearly stated, and the validity of legal norms is clearly distinguished from their actual enforcement.

The pure theory's Ought is about whatever the law requires to be (i.e. to happen or to take place), not about what the law itself (its content) ought to be. It is not a matter of opinion or assessment but an imperative emanating from the constitutionally empowered authority. This is different from Hart's take that " $[\mathrm{t}]$ he word "ought" merely reflects the presence of some standard of criticism', which is a jurisprudential tool for assessing the substance of specific legal systems as a good system or evil system. ${ }^{44}$ This may embody some reformist outlook or agenda or, alternatively, an aspiration to disregard or disobey the existing law.

In other words, it may be queried whether an Ought contained in the existing rule of law should be of a different content, or whether another Ought should be created that does not currently form part of the existing law. We might contemplate whether it is a good idea to ban cycling in the park, or whether baby prams should also be banned alongside with bicycles. Kelsen's Ought would merely suggest that no one ought to cycle in the park, and it suggests nothing as to baby prams, because its content and scope do not extend to them. Thus, an Ought is merely about what the law actually is, not about what it should be, still less any form of criticism or desire of the improvement of the existing law. It may well be that concerns arise that the reason and rationale for which

43 Gul, para. 36.

44 HLA Hart, Positivism and the Separation of Law and Morals, 71 Harvard LR (1958), 613. 
cycling in the park is banned (for instance the avoidance of congestion) might also require banning baby prams, but the pure theory does not consider these concerns to be part of the object of jurisprudence.

Kelsen explains that the approval or condemnation of conduct in defiance of or in compliance with a legal norm is just as separate from the norm's own validity ${ }^{45}$ as are the social policy and interest that lead the norm's author to adopt the norm. The legislator's will embodied in a legal norm and any person's reaction to that norm's content are two different things. The legal bindingness of a norm is different from its motivating element, especially psychological motivation; motivation can follow from factors other than legal norm. ${ }^{46}$

At another level, the emphasis on the relevance of the authority and its will requires the separation of considerations and interests that lead the authority to enact a particular norm, and the content and effect of that norm thus enacted, between motive and product. Motives derive from social forces whose interests are given expression by the authority, the product derives from the will of the authority; law thus becomes an ordering mechanism. Consequently, the law is a regulator of interests and policies, not their mirror-image.

If the motivation and good sense of people are placed by the jurisprudence on the same footing as the normativity of the law, or the content and binding force of a legal rule, then law is essentially constituted through practice of people, not through constitutional authority. However, the motivating imperative motivates only those motivated, the deterring effect deters only those deterred; and none of these factors explains what the rule means for those who are neither motivated nor deterred.

\subsection{SOME BASIC METHODOLOGICAL TOOLS}

As the regulatory function is law's chief function, particular techniques of regulation acquire increasing relevance. The way the pure theory uses the relevant tools is driven by the inevitable place the relevant concepts and techniques possess in any legal order: concepts and techniques without which legal orders cannot function. In other words, it is not the pure theory that constructs these tools and concepts but instead the pure theory identifies the ways in which the legal order itself constructs those tools and concepts to be able to carry out its regulatory function.

To begin with, the very concept of legality and illegality has nothing to do with natural reality. Instead it depends on the qualification bestowed by the

45 Hauptprobleme, 16.

46 Hauptprobleme, 55, 71. 
law upon the relevant conduct. To say that an act being a murder is a natural reality would be to advocate the contradiction of law with reality in circumstances when the law considers some killings to be a murder and others not to be murder. ${ }^{47}$ Some acts of homicide could well amount to manslaughter, action in self-defence or execution of a court sentence. To say that illegality is a natural fact is to blame the law for not considering the above acts as murder and thus criticise the law. Similarly, and following the imperatives of public policy, a legal system may describe as murder an act that would constitute a mere manslaughter in the eyes of an ordinary person. Yet it would be solely the legal order's judgement, not natural characteristics or ordinary perception of the relevant acts that would determine what their legal classification is.

Definition of a person as a 'personified unity of a set of legal norms' relies on the fact that a man is a concept of biology and natural reality, while a person is a concept created by a legal order, a construction of juridical thinking. There is no essential difference between the concept of a natural person and that of a juridical person. ${ }^{48}$ Both are created by the law the way that the legal order considers them to be appropriate to operate. Kelsen similarly specifies that acts of juridical persons are always acts carried out by human beings. Therefore the legal order needs criteria to determine when these human beings should be seen as acting as organs of the juridical person. ${ }^{49}$ Those 'fictions' the legal order creates are not fictions at all, because the legal order creates them not through reflection but through the expression of will. ${ }^{50}$

Kelsen's take on legal personality is fully in accordance with the positivist outlook of the pure theory. Positive law does not borrow or incorporate the relevant concepts from elsewhere, but it creates them itself. Jurisprudence then identifies and acknowledges those concepts, and uses them for its own jurisprudential analysis. Legal personality, even that of an individual, is not a creation of natural reality, it is a construct of law; it is moreover the product of socio-ethical judgement, the regulation as to the age at which crimes should be imputable to an individual or at which the contractual capacity should be enjoyed is by no means a mirror-image of some natural reality. It is, therefore, the reflection by the legal order of one of the several social policies and

\footnotetext{
47 “"Unrecht” ist ja keine Naturtatsache. Ein Tatbestand ist "Unrecht" nur durch sein Verhältnis zur Rechtsordnung', H Kelsen, Zur Theorie der juristischen Fiktionen. Mit besonderer Berücksichtigung von Vaihingers Philosophie des Als Ob, 1 Annalen der Philosophie (1919), 630 ('Fiktionen'), 643.

48 GT, 93-4; see also 'Mit der Rechtsperson wird eine natürliche Realität behauptet, die es nie und nirgends in der Wirklichkeit gibt. Das gilt in gleicher Weise für die "physische" wie für die sogenannte "juristische" Person', Fiktionen, 637.

49 GT, 97.

50 Fiktionen, 638.
} 
opinions on this matter and the endowment of the outcomes preferred by those policies and opinions with the force of law.

Another pertinent example is the meaning of fatherhood. A legal order may wish to extend the meaning of fatherhood and include both natural and legal fathers. That would be, in a way, a statement of falsehood that is not allowed to be traversed under the legal system. The law may place both natural and other fathers in a similar or identical position in terms of family and inheritance relations (which may be done by way of establishing a rebuttable presumption or otherwise equalising them in status). But would that be the same as the extension of the term 'father'? It may be said that fatherhood is a natural reality and the law seems to require deviation from such natural reality when it creates such fiction. On the other hand, fatherhood may be said to be also a social reality to be contextualised with the institutions of family and upbringing, which factor may require the law's refusal to be premised on biological realities. Thus, there can be two or more different extra-legal considerations dictating what shape a particular concept should have. However, it is the positive legal order that creates the relevant legal concept through the expression of its discrete and separate will derived from the law-making authority, not from extra-legal considerations themselves.

The law merely makes a choice between competing concepts of fatherhood and in doing so it creates no fiction that would contradict natural reality. The law just provides the singular legal definition of fatherhood for the purposes of the legal system, as opposed to working out first a mainline definition of fatherhood that would be identical with natural fatherhood, and then specifying that in certain cases persons other than natural fathers have to be considered as fathers. ${ }^{51}$

Another principal analytical tool the pure theory operates with is imputation. One aspect of imputation relates to criminal responsibility of individuals, whether they are capable to be imputed a crime, which persons under the liability age and those of unsound mind are not. This is not a delict on the account of harm caused but on the account of having been committed by a person which the legal system considers to be capable of imputation: an adult of sound mind. ${ }^{52}$

But the more general essence of the imputation tool is the classification of the relevant acts so that we can see whether they are acts of State under the legal order. The legal order may assign different legal meanings to two or more

51 'Eine Fiktion im Sinne eines Widerspruches zur Wirklichkeit vollzöge sich erst dann, wenn man diesen Rechtsbegriff des, Vaters' mit 'der Naturtatsache des so benannten männlichen Erzeugers identifizierte', Fiktionen, 641.

$52 G T, 92$. 
similar or identical acts. Kelsen speaks of the concept of imputation different from that which deals with attribution of responsibility for a crime or delict. This is an imputation through the legal order bestowing a particular classification or characterisation to the acts and conduct of individuals or, in Kelsen's own words, determining them in a special way. ${ }^{53}$ And 'an act performed by a human being may be imputed to the state if this act is determined by the legal order in a specific way'. ${ }^{54}$ This way the legal system imputes the particular character or status to the particular activity or conduct, as opposed to imputing the violation of legal rules to a person.

The distinction between the tools of fiction and imputation is that fiction deals with creation of legal concepts by the legal system the way that those legal concepts do not have a ready-made equivalent in the natural reality; while imputation deals with the legal distinction between similar or identical facts or phenomena of natural reality. In other words, two or more natural phenomena might have similar or identical natural characteristics, and the legal system may yet differentiate between them by bestowing different classifications to them. This differentiation may then be reflected down the line in terms of legal consequences attached to every such particular conduct.

It seems that, of all legal techniques discussed here, imputation possesses the greatest analytical relevance, particularly in terms of enabling the legal system to regulate conflicting interests and find balance between competing values. ${ }^{55}$

\subsection{CRITICS OF THE PURE THEORY}

Lauterpacht has observed that Kelsen challenges all theories and that ' $[\mathrm{t}]$ here is hardly a leading doctrine or conception of modern jurisprudence that [Kelsen] has not assailed'. ${ }^{56}$ Lauterpacht continued that, 'Kelsen's theory has been the subject of protracted controversy at almost every point, and anyone at all familiar with the voluminous anti-Kelsen literature might wonder whether there was anything to be saved from the wreck' ${ }^{57}$

The reaction of the English legal doctrine to the pure theory has been either dismissive or partial. Brian Simpson has suggested, in a rather counter-factual manner, that 'Kelsen does not really develop the application of his theory to

\footnotetext{
$53 \quad G T, 99$.

54 H Kelsen, Law, State and Justice in the Pure Theory of Law, 57 Yale Law Journal (1948), 377 ('YLJ'), 381.

55 On which, see further Ch. 3.

56 Lauterpacht, 105-6.

57 Harris, CLJ (1977), 355.
} 
common law' ${ }^{58}$ This also overlooks the fact that Kelsen presented his pure theory to the English-speaking audience through the Law Quarterly Review in the mid-1930s, and his work is replete with observations with which common law thinking should be comfortable. At times, critiques of Kelsen address his theory at its margins, but not with regard to the mainline arguments of the pure theory, as exemplified by Hart's handling of three selected issues. ${ }^{59}$

On the other hand, Kelsen has also been described as the 'most instructive outsider' to observe common law. ${ }^{60}$ Sir Arthur Goodhart has described Kelsen's theory as analytical successor to the Austinian command theory, with the difference that the pure theory substitutes sanction for the power and command with which the Austinian theory operated. ${ }^{61}$

It may also appear attractive to accuse the pure theory of disregarding practical realities in its pursuit of logical coherence. Even in German jurisprudence this view has been held, with the claim that the purity of legal analysis pursues no immediate practical aims and merely aspires for logical peculiarity and methodical self-sufficiency. ${ }^{62}$ However, it is unclear why creation, content and application of legal norms can have no practical implications, why practical relevance always has to do with the relation of legal with non-legal factors or requires identity between them; and more broadly, how practical aims can be ascertained or analysed without methodological consistency.

The problem with the above criticism is that it projects an insurmountable dichotomy between our use of scientific method and our ability to understand practical realities. Instead, practical realities are part of the process through which the overall system functions and are accounted for by broader factors and considerations. It is perfectly feasible and legitimate to analyse the law from a coherent scientific perspective and thus figure out its real impact on practical realities.

It remains the case that English law has never been properly or systemically examined through the prism of the pure theory. Doing so, now for the first time, can help understanding of aspects of English law through the rigour, accuracy and completeness of analysis that the pure theory offers; complete

58 AVB Simpson, Common Law and Legal Theory, Oxford Essays in Jurisprudence, Second Series (1973), 83.

59 HLA Hart, Essays in Jurisprudence and Philosophy (1984), $284 \mathrm{ff}$.

60 Cotterrell, 107.

61 Goodhart, 14-15.

62 Larenz, 74-5, 'So wie die Interessenjurisprudenz als Theorie mangelhaft, fur die Praxis aber von grossem Nutzen gewesen ist, so ist die "Reine Rechtslehre" als Theorie in hohem Masse bestechend, ihr Ertrag fur die Praxis aber gering. Das hat aber zuletzt seinen Grund wiederum in einem Mangel der Theorie'. Larenz then suggests that "Der "Reinen Rechtslehre" geht es um die logische Eigenart und die methodische Selbstandigkeit der Rechtswissenschaft', ibid., 77. 
theory to relate to the wide empirical ground to which it has not so far been properly brought. 